\title{
Initial Planning and Estimation of 2.4 Kw Solar Power Plant Using PVsyst Software in Faculty of Engineer- ing, Sultan Ageng Tirtayasa University - Cilegon Banten Province
}

\author{
Rocky Alfanz ${ }^{* 1}$, M. Otong ${ }^{1}$, Fulka Zaidan ${ }^{1}$, Imron Rosadi ${ }^{2}$, Putro F Ferdinant ${ }^{2}$ \\ ${ }^{1}$ Electrical Engineering Department Universitas Sultan Ageng Tirtayasa \\ Jendral Sudirman Street Km. 3, Cilegon, Banten \\ ${ }^{2}$ Photovoltaics Module Quality and Sensors Instrument Laboratory, \\ Centre of Excellent Universitas Sultan Ageng Tirtayasa Jendral Sudirman Street Km. 3, Cilegon, Banten \\ *Corresponding author. Email: rocky.alfanz@untirta.ac.id
}

\begin{abstract}
Indonesia is located in an equatorial region with an abundance of solar energy, with an average solar radiation intensity of $4.8 \mathrm{kWh} / \mathrm{m} 2$ per day. It can be used to build solar power plants. This research aims to estimate and plan the efficiency of a solar farm so that the power produced in the faculty of engineering at the university Sultan Ageng Tirtayasa Cilegon, Banten. In accordance to the desired and can avoid power loss caused by miscalculation of specifications such as photovoltaic (PV) modules with capacity $2.4 \mathrm{~kW}$ att peak $(\mathrm{Wp})$, battery, solar charge controller, or inverter used. The method used is to predict by influenced factors such as shading, a tilt of solar modules, cable use, and natural factors. The calculated power generated after that analysis for solar power plants can be done using PVSyst software applications. PVSyst is used to do calculation simulations for solar power plants with a $2.4 \mathrm{kWatt}$ capacity at a given location that will be charged four times with a 36 Volt and a current of 2 Ampere for a duration of three hours
\end{abstract}

Keywords: Solar Power Plant, PVSyst, Photovoltaic Modules. Solar Farm Efficiency

\section{INTRODUCTION}

A solar power plant (PLTS) is a power plant that converts solar photon radiation into electrical energy using solar cells (photovoltaic). PLTS success in Indonesia was heavily influenced by a number of factors. Environmental parameters, PV module temperature factors, meteorological conditions, and sunshine intensity factors are among them [1]. In one day, solar cells receive sunlight illumination varies greatly. This is due to the fact that sunlight is much more intense during the day than it is in the morning. On the gums of solar cells called modules, current (I) and voltage (V) measurements are taken to assess the capacity of the power produced [2]. Solar cells have emerged as a highly promising energy source. Sunlight falling on the surface of a solar cell area of one square meter will create 900 to $1000 \mathrm{~W} / \mathrm{m} 2$ of electrical energy in its peak state, or when the sun's position is perpendicular. Thin layers of pure silicon $(\mathrm{Si})$ semiconductor material and other semiconductor materials make up solar cells. PLTS generates DC electricity from sunlight, which can then be converted to AC electricity using an inverter if necessary. As a result, even in cloudy weather, PLTS can generate power as long as there is light [3]. Because PLTS is a power supply, it can meet a wide range of electricity needs, either alone or in combination (combined with other energy sources). PLTS can alternatively be developed using one of two approaches: decentralized (one residence, one generator) or centralized (distributed electricity) with a grid connected network [4].

The research methodology of initial design by PVsys software for solar plant mini-grid has three types. First, there's PLTS Off-grid/Self-contained. It is a standalone PLTS system that is not connected to the grid [5]. There is PLTS On-grid, which connects its system to the grid or an existing system. PLTS Hybrid is the final option [6]. 


\section{METHODS}

To measure the maximum current, the two terminals of the module are short-circuited, resulting in a voltage of zero and a maximum current. A maximum current called short circuit current can be obtained by using a current meter (Isc). By not connecting solar cells to other components, voltage (V) is measured on the positive and negative terminals of solar cell modules. Open circuit voltage is the term for this measurement (Voc) [5]. On the I-V curve, the maximum Power Point (Vmp) and (Imp) are operational points that show the maximum power generated by solar cell panels. Isc is the maximum output current of a solar cell panel that can be expelled in conditions of no resistance or short circuit, whereas Voc is the maximum voltage capacity that can be produced in the absence of current equation 1. Equation 2 can be used to compute the short circuit current. The Fill Factor is a metric that controls how much power solar cell panels can produce. To compute the electrical power in the PVSys software aplication, equation 3 in the technique will utilize a formula based on the formula from Voc, Isc, and fill factor.

The highest voltage capacity that may be achieved in the absence of current is known as open circuit voltage (Voc). The following is the equation:

Voc $=\mathrm{kT} / \mathrm{q} 1 \mathrm{n}(\mathrm{Isc} / \mathrm{Is}+1)$

Where,

$\mathrm{k}=$ boltzmann constant $(1.30 \times 10-16 \mathrm{erg})$

$\mathrm{q}=$ electron charge constant $(1.602 \times 10-19 \mathrm{C}$

$\mathrm{T}=$ temperature in Kelvin

Is $=$ Saturation current

The greatest output current from a solar cell panel that may be supplied under no resistance or short circuit conditions is known as the short circuit current (Isc) [5]. The following equation can be used to calculate the short circuit current:

$\mathrm{Isc}=\mathrm{qG}(\mathrm{Ln}+\mathrm{Lp})$

Where,

$\mathrm{G}=$ generation rate

$\mathrm{Ln}=$ electron diffusion length

$\mathrm{Lp}=$ hole diffusion length

The Fill Factor is a characteristic that controls how powerful solar cell panels may be [1]. The following formula can be used to calculate the amount of FF:

$\mathrm{FF}=(\mathrm{Vmp} \times \operatorname{Imp}) /($ Voc $\times$ Isc $)$

In general, use the following formula to predict the requirement for solar power plants, as well as the preparation of components such as solar panels, batteries, inverters, and solar control panels, all of which will be estimated with precision and accuracy.

\section{RESULTS AND DISCUSSION}

To begin using the PVSys program, navigate through the numerous menus to select the type of PLTS to utilize and the design you wish to create. Because the system utilized in this solar farm is Off-Grid or stand alone, the menu selected is Project Design > standalone (see Figure $1)$.

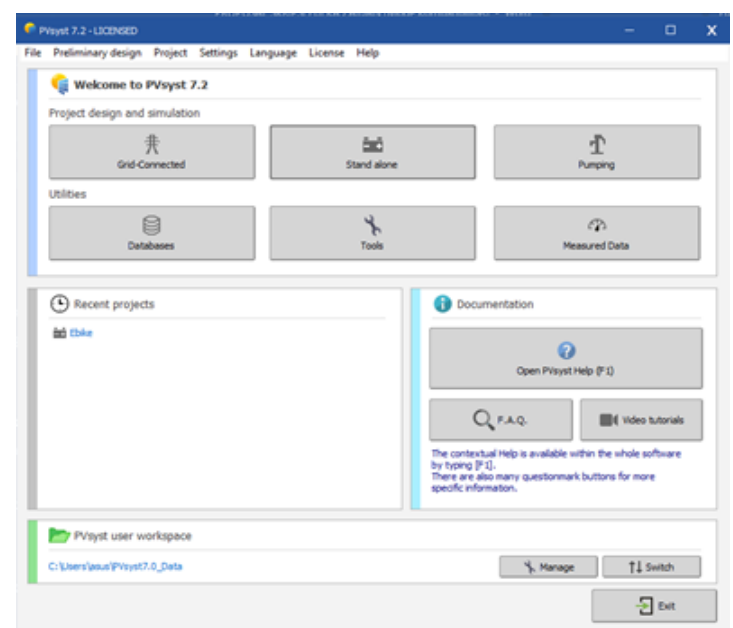

Figure 1. PVsyst project design selection

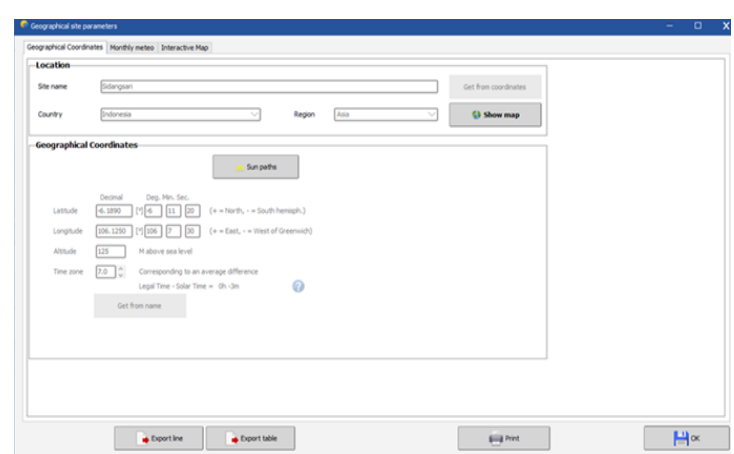

Figure 2. Determination of the location coordinate graph

The next step is to construct a database based on the PLTS location after you've decided on a project design. As shown in Figure 2, the PLTS location points can be calculated by entering coordinates or by adding the location points to a map. Select the Meteo data that will be imported next. Use Meteonorm 8.0 to import the most recent weather data. The Monthly Meteo data will be automatically filled after importing data from Meteonorm 8.0, as illustrated in Figure 3.

The GHI value in Cilegon City - Banten Indonesia is $4.87 \mathrm{kWh} / \mathrm{m} 2$ per day, according to the Meteonorm 8.0 data collection, and the determination of the position coordinate graph can be shown in Figure 2. It will then go 
to the PVsyst application's start page, as seen in Figure 4. The initial step in the simulation process is to calculate the system. As shown in Figure 5, the computation begins by identifying the direction of the solar panels.

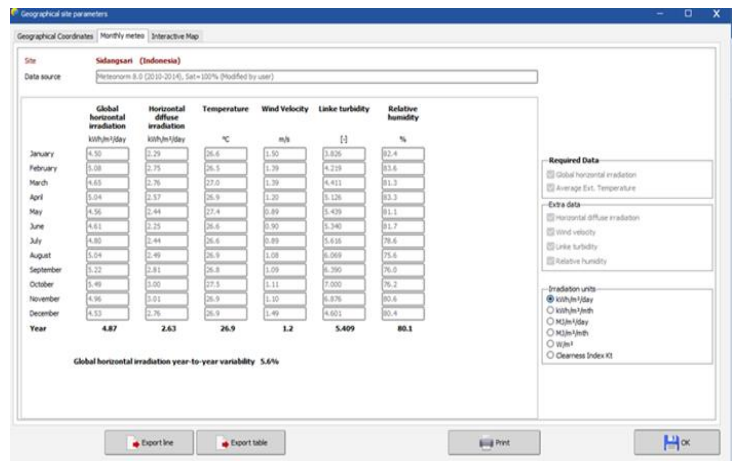

Figure 3. Monthly meteo data from Meteonorm 8.0

The outcome may be seen in Figure 3 for orientation determination, which seeks to identify the most appropriate angle based on the sun's velocity. The proportion of electricity lost (loss) in a year can be used to determine the performance of solar panels. The field is the building's flat roof, which is not equipped with a solar tracker. PV systems can be configured with the most effective tilt angle of 9-15 degrees and the most suitable azimuth angle of 0 degrees. The loss of the solar panel owing to the orientation angle for one year is $0 \%$ with this angle.

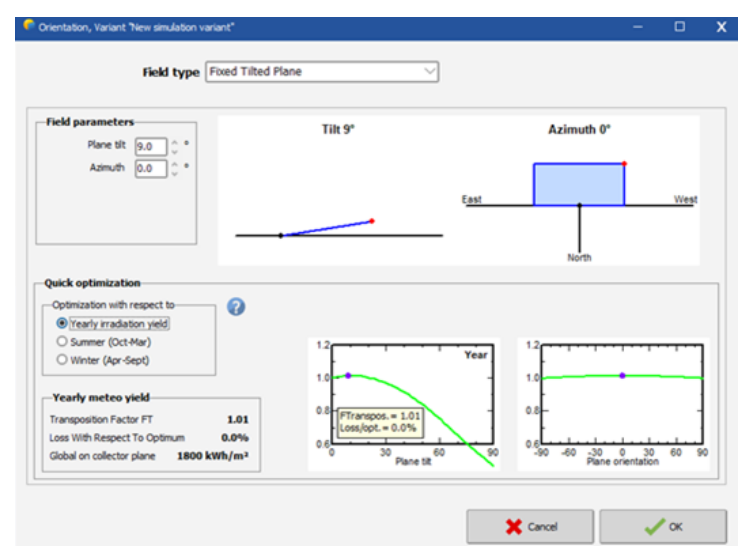

Figure 4. Determine of PLTS solar panel orientation

Figure 4 shows how this PLTS design and implementation is used to charge two electric bicycles (e-bikes). Maximum speed is $20 \mathrm{~km} / \mathrm{h}$, with a $15 \mathrm{~km}$ range. Brushless motor DC $36 \mathrm{~V} 180 \mathrm{~W}$ dynamo Charger station provides: Lithium charger $36 \mathrm{~V}, 2 \mathrm{~A}$ output $=72$ Watt, capacity battery: $36 \mathrm{~V} 5.2 \mathrm{Ah}=187.2 \mathrm{Wh}$, controller: brushless dc motor controller with a maximum current of $12 \mathrm{~A}$, and capacity battery: $36 \mathrm{~V} 5.2 \mathrm{Ah}=187.2 \mathrm{Wh}$. As a result, the approach is as follows: the next calculation result is the load or energy required on the PLTS. The purpose of estimating the load is to use generic equations to adjust the characteristics of the system to be developed, such as solar panel, battery, solar charger controller, and inverter. So, the electric bike as a single load as reference on this simulation. This PLTS design can power two electric bicycles, allowing the total energy required to be entered into the PVSys software application with the value of power per hour in units of day (daily needs). The required power per hour is equivalent to two $72 \mathrm{~W}$ bicycle chargers or $144 \mathrm{~W}$ per hour. The simulation PVSys program shows how much power one bike consumes.

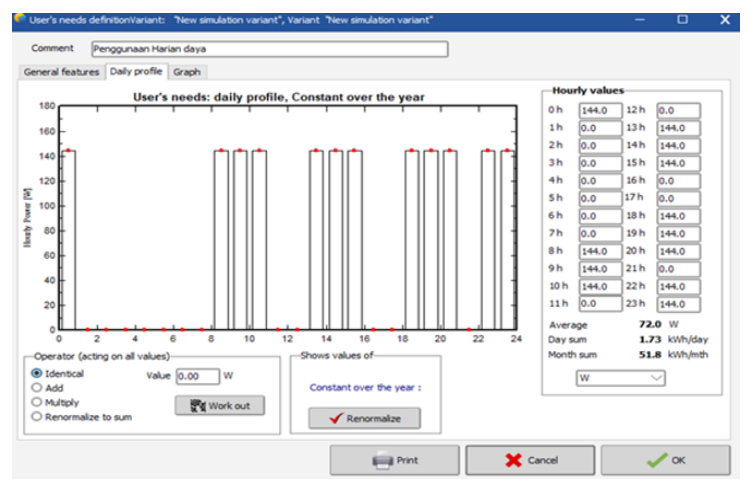

Figure 5. PLTS system load data

As a result of the initial design, the number of bicycles used starts from the fully charged state of each battery. With a power of $187.2 \mathrm{Wh}$, the bicycle may be operated from 06.00 to 21.00 with a total of 4 charging periods. On a single charge, the bike takes 3 hours to charge. As shown in Figure 6, the load with the highest utilization is $1.73 \mathrm{kWh}$ per day.

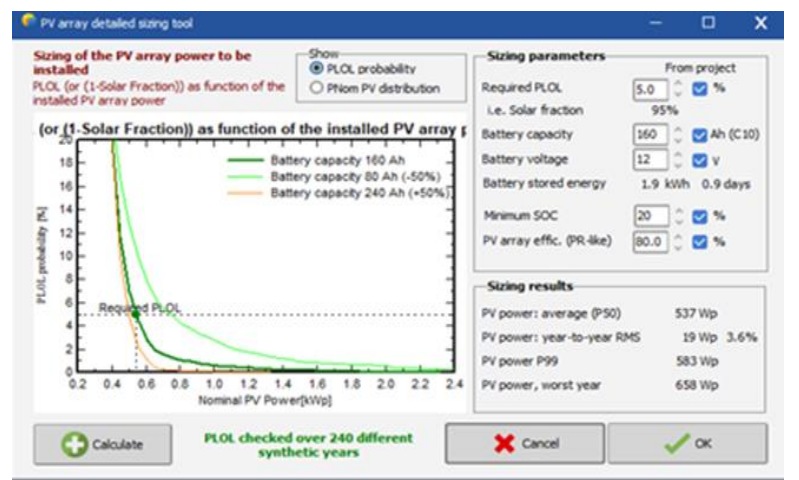

Figure 6. Loss of Load Probability 
The PLTS system appears in the PVSys simulation as batteries, solar panels, and SCC. The system determination technique starts with pre-sizing to determine initial measurement conditions such as LOL (loss-of-load), autonomy and battery sizing, and battery voltage, as shown in figure 6. The LOL value is based on the project that will be developed when the simulation is completed, which is $5 \%$, with this number being the percentage of the possibility that the PLTS will not function in a year.

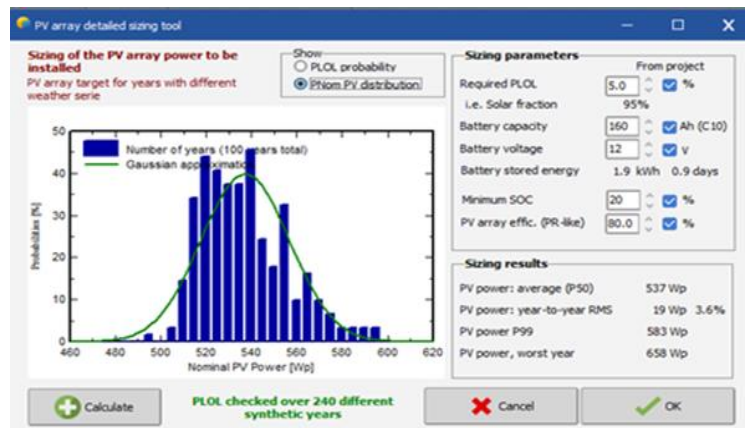

Figure 7. Nominal probability of PV module distribution

The LOL value is based on the project that will be developed when the simulation is completed, which is $5 \%$, with this number being the percentage of the possibility that the PLTS will not run in a year. Figure 6 shows how LOL should refer to the likelihood of a load loss. It is possible that the load will not be activated. The value of autonomy is 1 day, and the battery sizing is the number of days it takes to charge the battery. The voltage of the batteries utilized is $12 \mathrm{~V}$. As a result, figure 7 shows the pre-sizing details.

It's possible that the load won't be brought on. The value of autonomy is one day, and the number of days it takes to charge the battery is the battery size. The batteries used have a voltage of $12 \mathrm{~V}$. Figure 6 depicts the presizing information as a result.

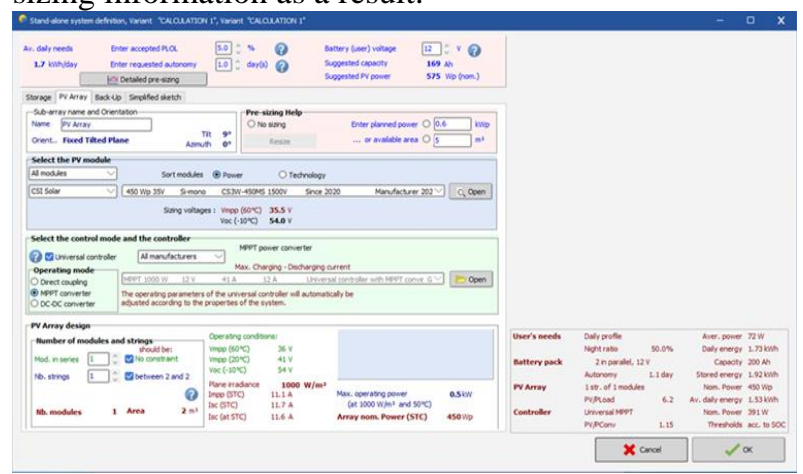

Figure 8. Determination of PLTS PV system storage
PV modules with a peak capacity of 450 watts are already available on the market $(\mathrm{Wp})$. As a result, the required number of solar modules is $450 \mathrm{Wp}$ of PV module. Figure 8 shows the selection of a PV module versus two or more modules to reduce roof use area. Following the determination of the system, the following step is to examine the system's detailed loss as determined by the I-V curve. Module quality loss, array mismatch, incidence angle effect, temperature effect, wire ohmic loss, and series diode loss are the parameters entered, as shown in Figure 9.

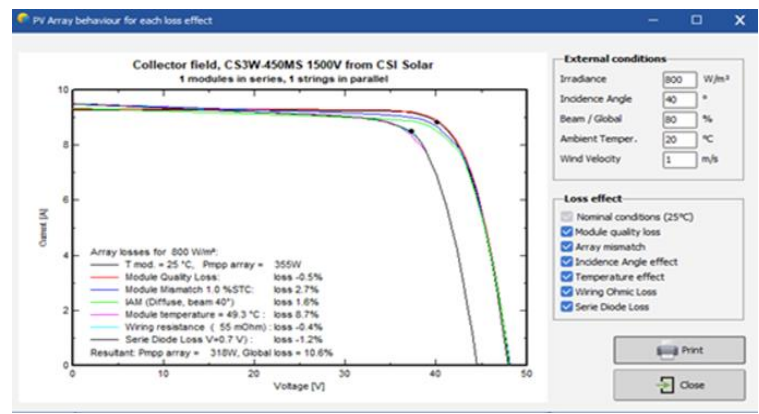

Figure 9. Curve I-V on PV modules Loss

Figure 9 shows the result parameter for each power loss in the module employed. The temperature, which accounts for $8.7 \%$ of the loss, is the most significant factor. The module has a total power loss of 10.6 percent. The current coming out of the solar panel can be used to determine SCC. The panel's current draw is $11.50 \mathrm{~A}$. As a result, the SCC used is MPPT 20A.

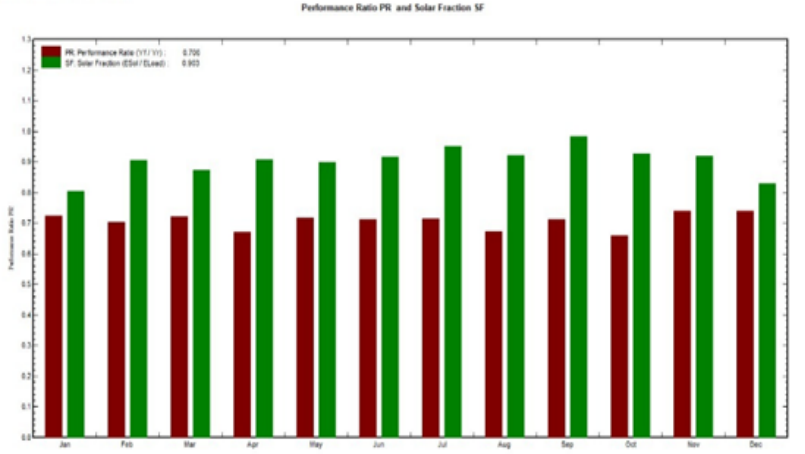

Figure 10. Performance ratio PR of solar Fraction

Because the PV is positioned far away from buildings or other impediments, the shading simulation result is 0 . Furthermore, as illustrated in Figure 11, the total simulation is carried out. 


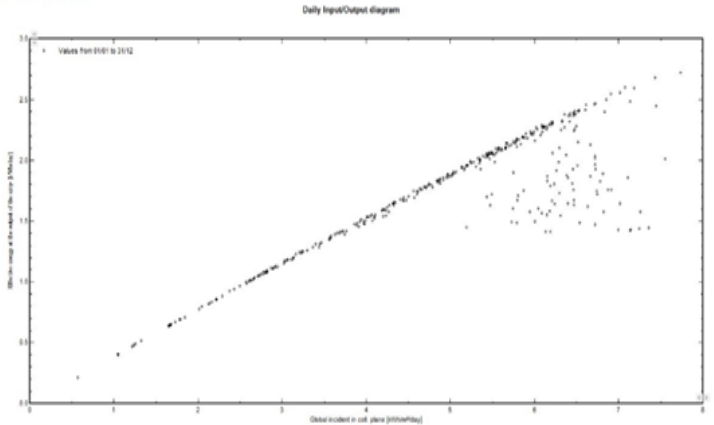

Figure 11. Daily input / output diagram

Figure 12 shows the PV effectiveness, which demonstrate that $\mathrm{PV}$ production ranges from 3.47 $\mathrm{kWh} / \mathrm{kWp}$ per day with a loss from the array of 1.1 $\mathrm{kWh} / \mathrm{kWp}$ per day. Meanwhile, the PLTS system's loss is negligible, at $0.3 \mathrm{kWh} / \mathrm{kWp}$ each day.

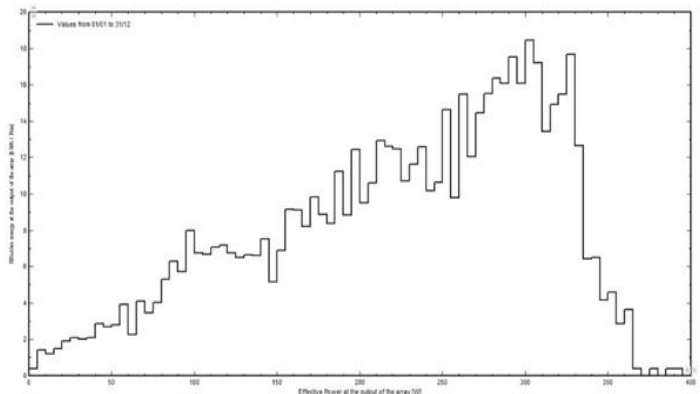

Figure 12. Array power distribution of the solar power

Figure 13 shows how a solar power plant with a battery capacity of $2.4 \mathrm{kWh}$ can satisfy the needs of two electric bicycles with a capacity of $187 \mathrm{Wh}$ over the course of four charging times. Since this voltage on an electric bicycle is DC, no inverter is involved; instead, a boost converter can be used to boost the voltage and adapt it to the bicycle battery input.

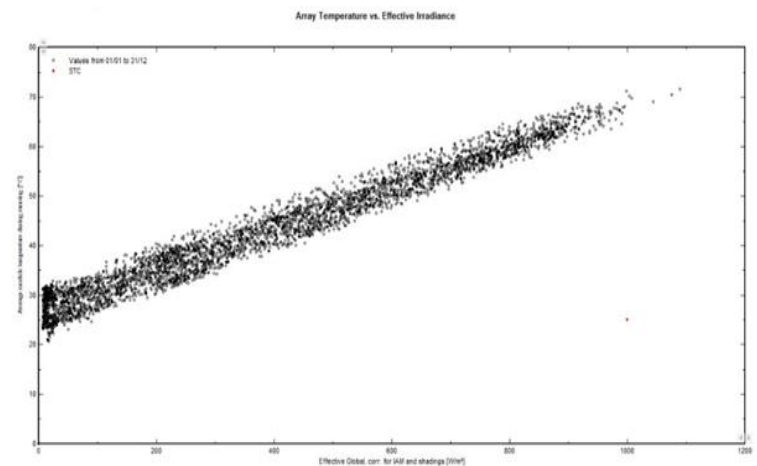

Figure 13. Array temperature vs effective radiation
Temperature causes the most loss in the module, accounting for $8.7 \%$. The system produces a total loss of $0.3 \mathrm{kWh} / \mathrm{kWp}$ each day. The ideal tilt angle for solar panels is 9-15 degrees to the tilt axis and 0 degrees to the azimuth axis. The specifications of the tools required before installation in the field at the solar power plant will be supported by the findings received from the PVSys software simulation.

\section{CONCLUSION}

PVSyst software application can take into account the components that must be utilized while planning a solar power plant. The simulation results will show component parameters such as solar modules, batteries, inverters, and SCC, as well as the probability of power output. A solar module with a capacity of $2.4 \mathrm{~kW}$ is the system that must be developed to generate electricity.

Furthermore, this software can evaluate the system's efficiency by displaying the resulting power output and comparing it to a graphic representation of the system. As a result, power loss in the system can be avoided. The simulation findings show that this system has a fairly decent efficiency, with a total efficiency of $>80 \%$, with the temperature being the most significant source of loss.

\section{REFERENCES}

[1] I.W.G.A Anggarara, I.N.S. Kumara and I.A.D. Giriantari, 2014 Studi Terhadap Unjuk Kerja Pembangkit Listrik Tenaga Surya 1,9 Kw Di Universitas Udayana Bukit Jimbaran," E-Journal SPEKTRUM Vol. 1, No. 1, vol. 1, no. 1, pp. 118-122

[2] Jatmiko, H. Asy'ari, and M. Purnama, 2011. Pemanfaatan Sel Surya Dan Lampu Led Untuk Perumahan," Semantik, vol. 2011, no. Semantik,

[3] R. Sianipar, 2014 "Dasar Perencanaan Pembangkit Listrik Tenaga Surya," vol. 11, no. 2, pp. 61-78,

[4] Cristiana Honsberg, Stuat Bowden, 1999, Photovoltaic Devices, system and Aplication PVCDROM 1.0, Australia.

[5] David, 2008 Tugas akhir Pemodelan dan simulasi fotovoltaic sistem dengan menggunakan PSIM, Jurusan Teknik elektro, Fakultas teknik, Universitas kristen petra, Jakarta.

[6] R Alfanz, H Haryanto, 2015, Rancang Bangun Penyedia Energi Listrik Tenaga Hibrida (PLTSPLTB-PLN) Untuk Membantu Pasokan Listrik Rumah Tinggal, Jurnal Setrum Vol.4, No.2 